\title{
Keep Coming
}

Sarah Wakeman, MD

Massachusetts General Hospital, Boston, MA, USA.

They shuffle and saunter

Strut and stagger

Through my open door

Week after week.

They banter and bargain

Beg and bellow

Make promises and deals

Tell stories, most true.

They lay bare

Their deepest wounds

Like the abscesses

I sometimes drain.

I return their calls

Make more time

Write letters to lawyers

Challenge deceit.

I held one man's hand

"People are scared of me"

Salty sorrow coursed

Over tattooed teardrops.

I return handshakes and hugs

Say to him, to them

I will be here

Keep coming.

Corresponding Author: Sarah Wakeman, MD; Massachusetts General Hospital, 122 Union Park, St., Apt. 1, Boston, MA 02118, USA (e-mail: swakeman@partners.org).

$\mathrm{J}$ Gen Intern Med 28(2):330

DOI: $10.1007 / \mathrm{s} 11606-012-2158-6$

Published online July 13, 2012

(C) Society of General Internal Medicine 2012 